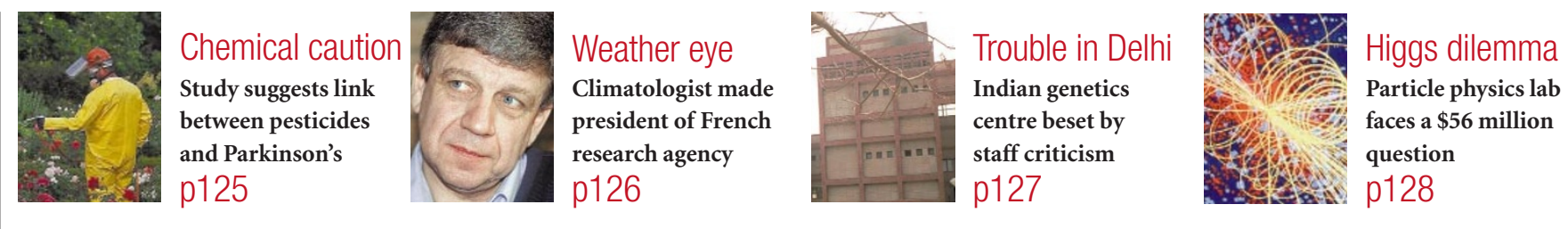

\title{
Emphasis of NASA's microgravity research shifts to space biology
}

\section{Tony Reichhardt, Washington}

As the long-awaited International Space Station becomes a reality - the first crew of one astronaut and two Russian cosmonauts boarded last week — the US space agency NASA is redirecting its controversial microgravity research programme towards the life sciences.

Future microgravity research will focus more on biology and biologically inspired technology, and less on the kinds of crystalgrowth experiments that yielded questionable results in the space-shuttle era.

Under the leadership of chief scientist Kathie Olsen, the agency has already reorganized its Office of Life and Microgravity Sciences and Applications, and given it a new name, the Office of Biological and Physical Research (OBPR).

More importantly, the office has been made an 'enterprise', on a par with human spaceflight and space science. The move reflects the importance that administrator Daniel Goldin has attached to beefing up his agency's capability in the biological sciences.

Nobel prize-winner Baruch Blumberg, who heads the agency's Astrobiology Institute, has been named a senior adviser to Goldin to help achieve this goal. Olsen will be acting administrator of the renamed office until a permanent leader can be found.

The creation of the OBPR is the latest of several shifts in NASA's microgravity and biology research programme in recent months. Long-time head of life sciences at NASA, Arnauld Nicogossian, who is widely

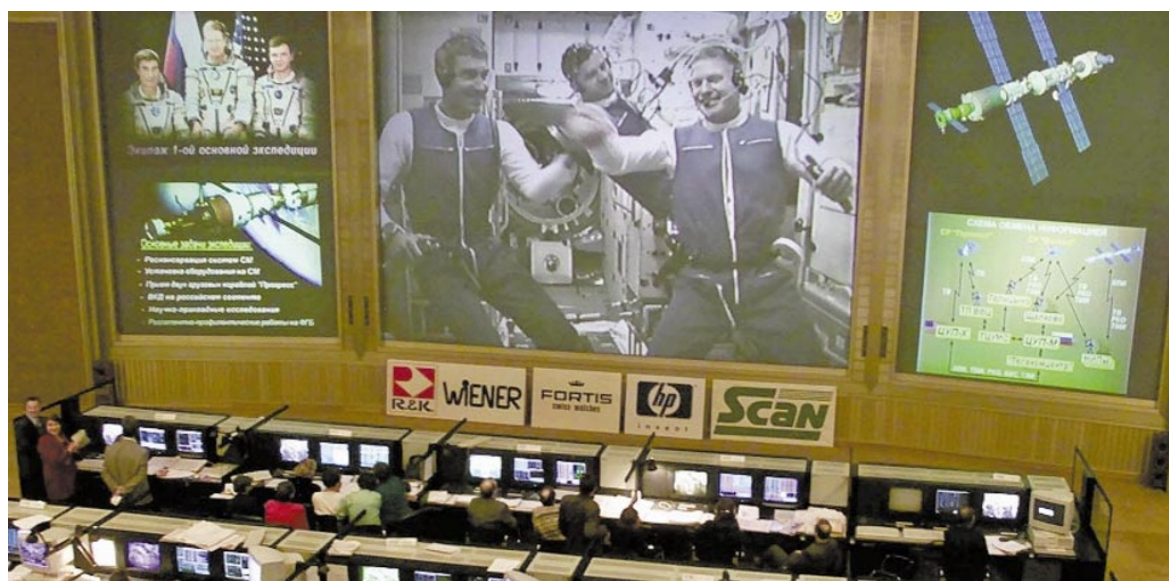

Action station: Russia's mission control welcomes the first crew to the International Space Station.

seen as more interested in astronaut health and 'space medicine' than other aspects of space biology, has been reassigned as the chief medical and health officer.

Other members of the old guard in the programme have retired, creating opportunities to hire younger scientists more versed in molecular biology and genomics.

Olsen and Blumberg are seeking leaders for OBPR's five restructured divisions: physical sciences (which incorporates much of the old microgravity research portfolio along with some new thrusts in nanotechnology); fundamental space biology; biomedical and human support research, which focuses on keeping astronauts healthy; research integration; and policy and programme integration.

The biggest changes will be in the physical

\section{US grad students win union rights}

Paul Smaglik, Washington

US graduate students working as research and teaching assistants at private colleges and universities have the right to form unions, the National Labor Relations Board ruled last week.

The case, which involves graduate student assistants at New York University, reverses a position the board has taken since the mid-1970s. The ruling could speed up the unionization of graduate students in private universities across the country.

Unionization at public universities has begun in several states, including Wisconsin, Michigan, California and New York. Attempts to unionize by graduate assistants in public universities are covered under state law, not under the National Labor Relations Act. sciences division, which spends about $40 \%$ of the office's $\$ 317$ million annual budget. Before, $90 \%$ of this went on basic research into the behaviour of materials and processes such as combustion in microgravity. Now, half of the research will be more applied, says the division's director, Eugene Trinh.

Work in different subdisciplines may be consolidated and streamlined, says Trinh. He adds that it will also be more focused on NASA's need to assure the safety of astronauts and their spacecraft.

The physical sciences division will also oversee a technology initiative dear to Goldin's heart - the development of tools and techniques in biomolecular physics that could someday lead to 'nanobots' capable of coursing through a Mars-bound astronaut's body, diagnosing and repairing disease without the need for a doctor.

NASA and the National Cancer Institute have formed a partnership to explore such research. Goldin envisages each agency spending around $\$ 10$ million a year for five years, although the cancer institute will invest just $\$ 6$ million this year. NASA will match that, and add a further $\$ 4$ million for related nanotechnology work.

Another key shift in the microgravity research programme is a retreat from NASA's long-hyped emphasis on protein crystal growth as a boon to drug developers and biotechnologists. 
A critical National Research Council panel found earlier this year that "one cannot point to a single case where a space-based crystallization effort was the crucial step in achieving a landmark scientific result" (see Nature 404, 114; 2000). The panel challenged NASA to instigate a grant programme to identify macromolecules important to structural biologists, which could be used to test the value of space-grown crystals once and for all.

NASA issued just such a call for research, with proposals due two weeks ago. Gary Stein of the University of Massachussetts Medical School, who chaired the panel at the time of the report, and who does not himself conduct space research, says: "I've never seen a report given to any group, let alone a government agency, where the recommendations were followed to this extent and with this speed."

Congress recently added $\$ 25$ million to NASA's 2001 budget for ground-based microgravity research, and ordered the agency to come up with a plan for doing research on the space shuttle while the space station is being built.

Opportunities for small-scale experiments are being explored for life scientists, says Olsen, including experiments 'piggy-backed' on other satellites.

But the space station will provide the most important opportunities. A crew that returned last week sailed through its construction tasks with apparent ease. Another crew will attach the US laboratory module in January.

At first, construction will take precedence over science. "I don't think in the immediate future we can have incredibly high expectations," says Stein.

But as the station nears completion in 2005 , better laboratory equipment, along with the chance to conduct long-term studies and repeat experiments, should create a "whole new generation of opportunities" in space research, he says.

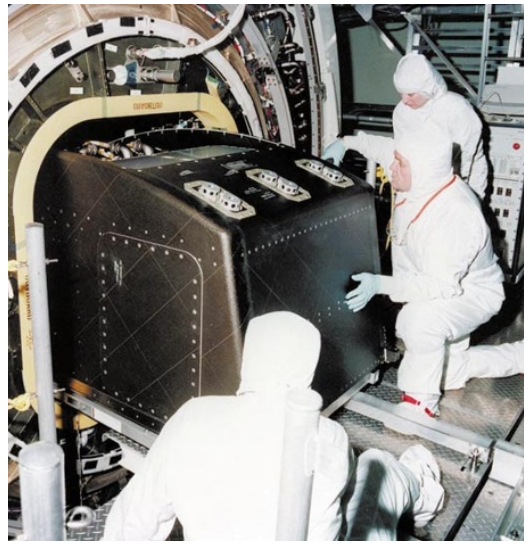

Gently does it: ground-based technicians assemble the space station's laboratory.

\section{Mexican science waits to see if election promises are met}

\section{Marina Chicurel, Santa Cruz}

Plans drawn up by president-elect Vicente Fox to bolster science and technology have received a cautious welcome from Mexican scientists. Scheduled to assume power on 1 December, Fox is the first president in 70 years to represent a political party other than the Institutional Revolutionary Party.

Fox gained a reputation as a supporter of science when he was governor of the state of Guanajuato from 1995 to 1999. And he has promised to double research and development (R\&D) spending as a proportion of Mexico's gross domestic product, and to increase the number of scientists.

Although they welcome his plans for science, many researchers are sceptical about how much will be delivered, given the current shortage of funding, the track record of past governments, and the lack of detail in the commitments.

But the team's coordinator of science and technology, María del Carmen Díaz, says big changes are planned. In addition to extra funding, the team promises to improve links between the academic world and industry, and to boost the political standing of science.

"Science seems to be more present in the minds of this transition cabinet than before," says neuroscientist René Drucker Colín, president of Mexico's National Academy of Sciences. "But science is not a political priority."

Mexican scientists have long complained about their lack of political status (see Nature 398, suppl. A7-A9; 1999). The country's main research funding agency, CONACYT, an arm of the Ministry of Public Education, has to compete with education for its budget.

To improve the situation, the academies of science, engineering and medicine recently proposed that CONACYT become autonomous, receiving its budget from Congress and answering directly to the president.

"Such a change in organization would send a clear message that science and technology are as important as human rights or clean elections," says Miguel José Yacamán, a physicist at the National Autonomous University of Mexico (UNAM) in Mexico City and former associate director of CONACYT, referring to the recent successes of other autonomous organizations, such as the National Commission for Human Rights and the Federal Electoral Institute.

Fox's team wants to relax CONACYT's link to education. Tessy López, a chemist at the Metropolitan Autonomous University in Iztapalapa, is an unofficial scientific adviser to Fox's team. She favours the less radical move of splitting education between two ministries: one to focus on postgraduate education and

๑ 2000 Macmillan Magazines Ltd research, and the other covering all other levels of education.

Díaz thinks this is not necessarily the best option, and Yacamán thinks it would not go far enough. But López says it would allow CONACYT to increase its power more gradually, and thus more effectively.

Another concern is the poor link between the academic world and industry. Economist Axel Didriksson of UNAM points out that the percentage of Fox: has a record of supporting science. research and development financed by pri-
vate industry in Mexico is less than a third of that of developed countries.

Many scientists are sceptical about whether the situation will improve, however, given that most of the international companies that have business interests in Mexico do their research in their countries of origin. And many Mexican companies are reluctant to invest in risky, long-term projects.

But researchers who dealt with Fox when he was governor of Guanajuato are optimistic. Mechanical engineer Arturo Lara, director of the Council for Science and Technology for the state, says that Fox established the first direct links between the state government, researchers and local industry, when he created the council in 1996.

As an example of the council's achievements, Lara cites an increase of about 30\% in the research and development budget of the state's main research institution, the University of Guanajuato.

Octavio Paredes, a biotechnologist at the Centre for Research and Advanced Studies of the National Polytechnic Institute (CINVESTAV) in Irapuato, says that, in contrast to previous governors, Fox listened to scientists' concerns. He took an active role in trying to deal with them, visiting research laboratories and inviting scientists to his office.

Fox also tried to implement long-term science policies, an innovation that would be widely welcomed at the national level. Paredes says the transition team is developing plans spanning up to 30 years, including an increase in the number of research centres in the country.

But all these plans are just words unless the new government manages to funnel more money into science. 